\title{
Gender Case Analysis: A Look at Recent IRB Decisions
}

\author{
Leanne MacMillan
}

The work of the Immigration and Refugee Board (IRB) has just begun to lend structure to the analytical framework that was proposed in the gender guidelines. It has been several months since the introduction of the guidelines, and a few cases decided by the Board are noteworthy.

In addition to those cases decided by the Board is the recent decision of Canada v. Ward [1993] SC] 74, June 30, 1993 of the Supreme Court of Canada. The meaning of "membership of a particular social group" was given greater expression and clarity. The Supreme Court's very extensive examination of the Convention refugee definition is discussed at length on page 16 of this issue.

The following summaries of two cases illustrate how the analytical framework proposed by the IRB in cases of women refugee claimants fearing gender-related persecution might be followed.

The framework of analysis proposed in the guidelines has been reproduced for the reader on page 12 .

\section{Case 1}

This case reviews 'membership of a particular social group' on the basis of persecution at the hands of private citizens from whose actions the state is unwilling or unable to adequately protect the concerned person. (Decision U92-06668, February 19, 1993.) ${ }^{1}$

The claimant, a 24-year-old woman born in Zimbabwe whose nationality was Zimbabwean, claimed to have a well-founded fear of persecution in Zimbabwe because of her membership in a particular social group.

The claimant was forced at age 14 into a traditional marriage with a wealthy, influential man several times her age. He

Leanne MacMillan, barrister and solicitor, is the coordinator of Legal Programmes at the Refugee Law Unit, CRS. had three wives senior to the claimant and thirteen children. The claimant was compelled to marry him ostensibly because her parents could no longer afford her school tuition fees and the future husband promised to do so. The claimant's parents received the bride's dowry despite her objections, and she was forced to join him in another city. He proved to be an alcoholic and very abusive. Within four months, he stopped paying her school fees, and what was to become almost a decade of physical and psychological abuse began.

On several occasions after being severely assaulted, the claimant appealed to the police authorities for relief, but to no avail. She was advised by the police that her problem was a domestic foundedness of her fear of persecution by reason of her membership of a particular social group. In establishing whether the claimant's fear of persecution was well-founded, the panel first established that the harm feared by the claimant amounted to persecution. In concluding that the treatment she was subjected to constituted persecution, several aspects of international human rights instruments were relied on, most notably, Articles 3 and 5 of the United Nations Universal Declaration of Human Rights, which state:

Article 3: Everyone has the right to life, liberty and security of the person.

Article 5: No one shall be subjected to torture or to cruel, inhuman or degrading treatment or punishment.

\section{In referring to these instruments, the Board concluded that the "continued physical, sexual, and emotional abuse constitutes a violation of the claimant's security of the person and amounts to cruel, inhuman and degrading treatment."}

affair, not assault, and she was never given any assistance. She was also told that the police could do nothing because she did not have a marriage certificate, and therefore was not officially recognized as the wife of her husband. Her pleas to her parents and to other relatives to repay the dowry went unanswered. Theclaimant twiceleft the "relationship" and fled to South Africa and Malawi, in both cases she was forced to return. In September of 1991, about one year after the birth of her second child, the claimant was severely beaten by her husband. She went immediately to the police, but they refused to take a written report. However, they did notify the husband that his wife had tried to make a report, and when she returned home she was beaten again. She fled Zimbabwe soon thereafter.

The claimant's testimony was found wholly credible and trustworthy, and the only issue was that of the well-
In referring to these instruments, the Board concluded that the "continued physical, sexual, and emotional abuse constitutes a violation of the claimant's security of the person and amounts to cruel, inhuman and degrading treatment."

The Board further relied on the United Nations Universal Declaration of Human Rights Article 16:

1. Men and women of full age, without any limitation due to race, nationality or religion, have the right to marry and to found a family. They are entitled to equal rights as to marriage, during marriage and at its dissolution.

2. Marriage shall only be entered into with the free and full consent of the intending spouses.

3. The family is the natural and fundamental group unit of society and is entitled to protection by society and the state.

Refuge, Vol. 13, No. 4 (July-August 1993) 


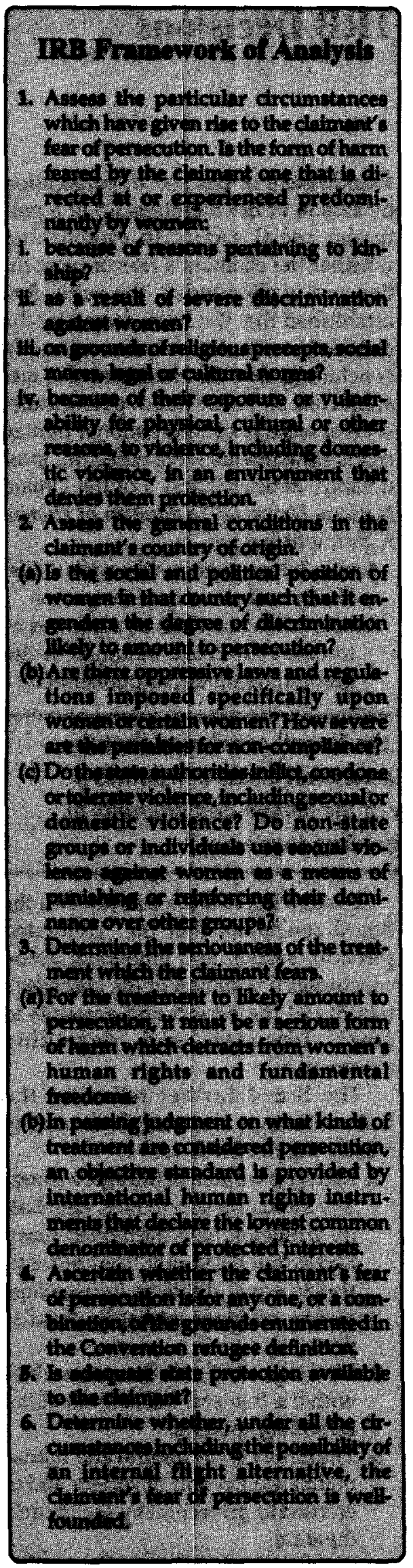

In further elucidating the basis upon which to decide if the treatment of the claimant constituted persecution, the Board also noted that the above mentioned fundamental human rights are reiterated in the International Covenant on Civil and Political Rights, Articles 7, 9 and 23. They also considered the recent Federal Court of Canada Appeal Division decision of M.E.I. v. Mayers (F.C.A. A544-92, November 5, 1992) and refugee law authorities.

In referring to Mayers they found that the case was helpful only insofar as it clearly stated that issues of women subject to wife abuse constitute a particular social group, and whether fear of abuse, given the indifference of the authorities, waspersecution was to be decided by the tribunal.

The Board relied on paragraph 51 of the United Nations High Commissioner for Refugees Handbook:

Paragraph 51: There is no universally accepted definition of "persecution", and various attempts to formulate such a definition have met with little success. From article 33 of the 1951 Convention, it may be inferred that the threat to life or freedom on account of race, religion, nationality, political opinion or membership of a particular social group is always persecution. Other serious violations of human rightsfor the same reasons-would also constitute persecution.

And, they relied on Hathaway in his book:2

persecution is most appropriately defined as the sustained or systemic failure of state protection in relation to one of the core entitlements which has been recognized by the international community. The types of harm to be protected against include the breach of any right within the first category, a discriminatory or non-emergency abrogation of a right within the second category, or the failure to implement a right within the third category which is either discriminatory or not grounded in the absolute lack of resources...

The categories to which Hathaway refers are:

1. basicnon-derogable rights (i.e., right to life, right to be protected from torture and cruel, inhuman and degrading treatment);

2. basic derogable rights (i.e., derogable only during times of emergency);

3. realizable or obtainable rights; and

4. rights which may be beyond the state's duty to protect.

In a very comprehensive application of international human rights instruments and authorities and an examination of the documentary evidence regarding Zimbabwe, the Board concluded that the harm the claimant feared amounted to persecution:

The documentary evidence indicates that Zimbabwean women have died at the hands of their husbands as a result of domestic violence; that wife battering and rape is endemic and country wide in Zimbabwe. ${ }^{3}$

The remaining issue of whether the claimant is unable, or by reason of her fear, unwilling to avail herself of the protection of the Zimbabwean authorities is determined according to the evidence of the claimant and the documentary evidence. The panel found that the documentary evidence clearly established that women, particularly from rural areas, generally experience serious discrimination at the hands of Zimbabwean male society; that physical abuse, rape and killings are an integral part of their abuse; that the authorities are notyet able to provide adequate safeguards to control the situation; and that the government is not above monitoring reports of human rights abuse from private citizens or soliciting the support of the state agencies to repress activities of human rights organizations.

The Board concluded that the claimant had reasonable grounds to fear that if returned to Zimbabwe the state would not protect her from persecution at the hands of her husband.

Since the Convention definition requires that the claimant's fear of persecution be linked to one of the enumerated five grounds, in considering the term "particular social group," the Board referred to the ordinary dictionary meaning for the word "particular." They were also guided by paragraph 77 of the United Nations High Commissioner for 
Refugees Handbookandby Hathaway's description of a social group:

This formulation includes within the notion of social group (1) groups defined by an innate, unalterable characteristic; (2) groups defined by their past temporary or voluntary status, since their history or experience is not within their current power to change; and (3) existing groups defined by volition, so long as the purpose of the association is sofundamental to their human dignity that they ought not to be required to abandon it. Excluded, therefore, are groups defined by a characteristic which is changeable or from which dissociation is possible, so long as neither option requires renunciation of basic human rights."

Accordingly, gender-based groups are clear examples of social subsets defined by an innate and immutable characteristic. This position supports that of the IRB in the "Preferred Position Paper on Membership in a Particular Social Group," that the determinative criterion is the nature of the membership in the social group and whetherit could readily be withdrawn by the individual concerned in order to avoid persecution.

In referring to Hathaway and the Preferred Position Paper, the Board found this claimant to have good grounds to fear persecution by reason of her membership in two particular social groups:

1. unprotected Zimbabwean women or girls subject to wife abuse;

2. Zimbabwean women or girls forced to marry according to customary laws of Kuzvarira and Lobala. 5

Theinnate and unalterable characteristic which defines the first group is that of their gender, which the group cannot repudiate, and which the documentary evidence regarding Zimbabwe clearly show places them at risk. Second, the practices of Kuzvarira and Lobola violate fundamental human rights. The Board concluded this decision by noting that the claimant's tormentor would likely always be able to retain control over her and have the power to persecute her without any reasonable expectation of effective state protection. Finding no available internal flight alternative, the panel found that the claimant was a Convention refugee.

\section{Case Two}

This decision relates to women who fear persecution resulting from acts of violence by public authorities from whose actions the state is unwilling or unable to adequately protect. (Decision V-9200883;-00884, March 23, 1993)

In this case the panel argued that one of the main reasons that the claimants had a well-founded fear of persecution was based on their fear of a gender-specific form of persecution-rape. This, coupled with the blatant racism and discrimination against their indigenous group established in the documentary evidence, completed the foundation of their claim.

The claimants were two sisters, aged seventeen and nineteen, from Guatemala. They are Mayan Indians with no

\section{Accordingly, gender-based groups are clear examples of social subsets defined by an innate and immutable characteristic.}

formal education who helped in the family enterprise of growing beans and corn. In mid-1990, they learned, as did the rest of their community, that their father was involved in the guerilla movement. Soon thereafter, their family was visited by soldiers on a number of occasions, and the claimants were threatened with kidnapping.

During these visits by the soldiers, the claimants were molested and threatened with rape and murder. The claimants were sent to another town where they found work in a cafeteria. Off-duty soldiers who were vacationing in the town recognized the claimants and harassed and threatened them with rape. The sisters fled Guatemala as soon as arrangements could be made.

The two sisters framed their refugee claims on grounds of a fear of persecution because of their race, their political opinion and their membership in a particularsocial group. The panel found that the claimants fell within a particular so- cial group-that of young Mayan women living without the protection of their families. In their opinion,

members of this social group are particularly vulnerable because of their age, gender, and race...these two women have been singled out and identified by members of the armed forces in Guatemala. This singling out happened because of their father's political opinion. They also could be subject to persecution because of their association with their father. However, it is because of their gender and their race that we find them to be particularly vulnerable and we find that the fear that they suffer, i.e. the fear of rape, falls within the definition of persecution. $^{6}$

The panel assessed whether there was a local flight alternative. They found that there was no local flight alternative given that they were very young women unaccompanied by their parents, and that they were Kanjobal-speaking Mayans with no formal education and with limited employment skills. The history of Guatemala's repression against Mayan Indians and its appalling human rights record with respect to their treatment of indigenous people also contributed to the panel's finding that the claimant's have a well-founded fear of persecution in Guatemala because of their membership in a particular social group.

\section{Notes}

1. While this decision was written two weeks prior to the date that the "Guidelines Issued by the Chairperson Pursuant to Section 65(3) of the Immigration Act Women Refugee Claimants Fearing Gender-Related Persecution" were released, it was clearly written according to the principles and framework of analysis enunciated in the guidelines. See also, Decision U92-08714, June 4, 1993 for a finding of "Ecuadorian women subject to wife abuse."

2. James C. Hathaway, The Law of Refugee Status, (Toronto: Butterworths, 1991), pp. 109-112.

3. Decision at p. 10.

4. Hathaway, supra note 1 at 161.

5. Kuzvarira is the practice of giving of young girls for marriage without their permission. Lobola is the custom of giving bride money for the purchase of a bride to the parents of the would-be wife.

6. Decision at p. 2. 